International Journal of Sustainable Agricultural Research

$\operatorname{ISSN}(e):$ 2312-6477

$\operatorname{ISSN}(p): 2313-0393$

DOI: 10.18488 journal.70.2017.42.50.57

Vol. 4, No. 2, 50-57.

(C) 2017 PAK Publishing Group. All Rights Reserved.

URL: www.pakinsight.com

\title{
HETEROSIS FOR NITROGEN FIXATION AND SEED YIELD AND
YIELD COMPONENTS IN CHICKPEA (Cicer arietinum L.)
}

\author{
Nigusie Girma ${ }^{1}$ \\ Firew Mekibib $^{2}$ \\ Asnake Fikre ${ }^{3}$ \\ Gemechu Keneni ${ }^{4}$ \\ Ganga Rao NVPR ${ }^{5}$ \\ Pooran Gaur ${ }^{6}$ \\ Chris O. Ojiewo ${ }^{7+}$
}

${ }^{1}$ Ethiopian Institute of Agricultural Research, Debre Zeit Agric Research Center, Debre Zeit, Ethiopia

${ }^{2}$ Haramaya University, Harar, Ethiopia

${ }^{3,7}$ International Crops Research Institute for Semi-Arid Tropics, Addis Ababa, Ethiopia

${ }^{4}$ Ethiopian Institute of Agricultural Research, Holleta Agricultural Research Center, Holleta, Ethiopia

${ }^{5}$ International Crops Research Institute for Semi-Arid Tropics, Nairobi, Kenya

${ }^{6}$ International Crops Research Institute for Semi-Arid Tropics, Hyderabad, India

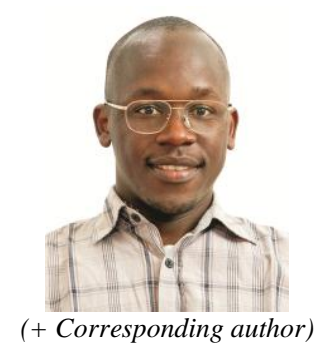

(+ Corresponding author $)$

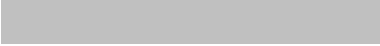

\section{Article History}

Received: 13 December 2016 Revised: 23 January 2017 Accepted: 16 March 2017 Published: 10 April 2017

\section{Keywords}

Chickpea

Cicer arietinum

Diallel

Heterosis

Hybrid

$N$-fixation

Nodule

\section{ABSTRACT}

Chickpea is one of the most cultivated grain legumes in Ethiopia for grain production and amelioration of soil fertility with less attention in research on $\mathrm{N}$-fixation. Therefore, this study was conducted to estimate the magnitude of heterosis for nitrogen fixation and yield and yield associated traits in chickpea (Cicer arietinum L.). Six F1 crosses obtained from crossing of four parents (two nodulated and non-nodulated) in a half diallel fashion were evaluated in 2014/15 season in lath house using Randomized Complete Block Design (RCBD) with two replications at Debre Zeit Agricultural Research Center. Significant $(\mathrm{P}<0.05)$ differences were exhibited among entries for all traits studied. Considering all traits, relative to the mid parent (MPH), better parent (BPH) and standard heterosis $(\mathrm{SH})$ in percent ranged from 0.009 to 59.8, 0.009 to39.9 and 0.009 to58.8, respectively. The highest degrees of MPH were noted for nodule dry weight and of BPH and $\mathrm{SH}$ were noted for number of pods per plant, while the lowest was observed for grain yield (0.009). The hybrid obtained from nodulated parents (ICC5003 x ICC19180) showed high heterosis for number of nodule on the basis of MPH and BPH, while ICC4918x ICC19181 exhibited low heterotic effect which exhibited positive and significant $\mathrm{MPH}$ for nitrogen fixed in grain, $\mathrm{BPH}$ for seed filling duration and $\mathrm{SH}$ for days to $50 \%$ flowering, days to $90 \%$ maturity and shoot dry weight at maturity traits.

\section{INTRODUCTION}

Chickpea (Cicer arietinum L.) is one of the most important food legume crops widely produced - globally on over 12 million hectares of land from which 10.9 million tons of grain is produced every year (FAOSTAT, 2012). It ranks second in area coverage (15.3\% of the total area allotted to food legumes) and third in volume of production (14.6\%) after common beans (Phaseolus vulgaris L.) and field peas (Pisum sativum L.) (Knights et al., 2007). In Ethiopia chickpea production ranks third in area and production among legumes next to faba bean and haricot bean (CSA, 2014/15). Out of 1.6 million hectares allocated for pulse, chickpea covered 239,755 hectares of land from 
which 458,682 tons of grain was produced, and the productivity was $1.92 \mathrm{t} / \mathrm{ha}$ (Central Statistical Authority (CSA), 2015). Chickpea is the cheapest and readily available source of protein (20\%-30\% \%), fats (1.4\%), carbohydrates (57-60\%), ash (4.8\%) and (4.9-15.59\%) moisture. It makes up the deficiency of cereal diets. From soil fertility management and water conservation point of view, production of chickpea plays a significant role in restoring soil fertility by fixing atmospheric nitrogen and contributes to agricultural sustainability (Gaur et al., 2010) and it can be produced under deficient moisture condition for most field crops. Therefore, targeted efforts to breed genotypes for improved $\mathrm{N}_{2}$ fixation and rhizobial symbiosis will bring benefits in increased yields of chickpea and will contribute toward sustainability of agricultural ecosystems in which soil-plant-microbe interactions enhanced.

The magnitude of heterosis provides a basis for determining genetic diversity and serves as a guide to the choice of desirable parents (Khattak et al., 2002). In grain legumes, the heterosis is generally due to dominance gene effects but also sometimes due to epistatic interactions (Khattak et al., 2002). Hence, the information regarding epistatic interaction is useful in planning a breeding program for development of pure lines with enhanced yield potential (Khattak et al., 2002). Therefore, this experiment was designed with the objective to estimate the magnitude of heterosis in chickpea genotypes for estimating symbiosis and yield and yield related traits

\section{MATERIALS AND METHODS}

Both the crossing and evaluation experiments were conducted at Debre Zeit Agricultural Research center (DZARC) during 2013-2014. Two nodulating chickpea (ICC5003 and ICC19180) and two non-nodulating genotypes (ICC4918 and ICC19181) were introduced from ICRISAT (Table 1) and crossed in half diallel fashion to develop $F_{1}$ generations as a mating design described by Griffing (1956) Method II Model I without reciprocal crosses. Sufficient amount of flowers were emasculated and pollinated to get $F_{1}$ generations. Crossing was done by hand emasculation and pollination using forceps to produce a total of six (6) hybrids. The four parental materials with their six crosses $\left(F_{1}\right)$ and two recently released standard checks (Arerti and Natoli) which are moderately nodulating were planted in Randomized Complete Block Design with 2 replication at Debre Zeit research experimental station using irrigation during 2014. Plant to plant and row to row distance was 10 and $30 \mathrm{~cm}$ respectively. Each plots consisting of 4 rows of 2 meters long. Two seeds were planted per hill and finally thinned to one plant per hill after 3 weeks of emergence. All other agronomic practice like weeding and irrigation was done as per recommendation. Data on Days to 50\% flowering, Days to $90 \%$ maturity, Grain production efficiency, Biomass production rate, Economic growth rate, Number of pods per plant, Biomass yield, Grain yield, Grain Harvest index, 100seed weight, Shoot dry weight at physiological maturity, Shoot dry weight ratio, Number of nodules, Shoot nitrogen fixation, $\mathrm{N}$ fixed in biomass, $\mathrm{N}$ fixed in grain, Nitrogen harvest index (NHI), Grain N yield, Shoot N yield, Biomass N yield, Nodule dry weight and Shoot and grain protein contents. N-content were determined according to Kjeldahl procedure at Debre Zeit Agricultural Research Center Soil Science Research Laboratory Association of Official Agricultural Chemists (AOAC) (1970).

Table-1. Phenotypes, nodulation characteristics and origin of the chickpea genotypes used for the study

\begin{tabular}{l|l|l|l|l}
\hline No & Genotype & Phenotype & Nodulation Characteristics & Origin \\
\hline 1 & ICC5003 & Desi & Nod $^{+}$ & ICRISAT \\
\hline 2 & ICC19180 & Kabuli & Nod $^{+}$ & ICRISAT \\
\hline 3 & ICC4918 & Desi & Nod $^{-}$ & ICRISAT \\
\hline 4 & ICC19181 & Desi & Nod $^{-}$ & ICRISAT \\
\hline 5 & Arerti & Kabuli & Nod $^{+}$ & DZARC \\
\hline 6 & Natoli & Desi & Nod $^{+}$ & DZARC \\
\hline
\end{tabular}

\subsection{Heterosis}

1. Heterobeltosis, the superiority of the $\mathrm{F}_{1}$ hybrid over its best parent $\left(\mathrm{P}_{1}\right)$, expressed as percentage: 
$\mathrm{HP}(\%)=\frac{\left(\mathrm{F}_{1}-\mathrm{P} 1\right)}{\mathrm{P} 1} \mathrm{x} 100$, where, $\mathrm{HP}=$ heterobeltosis, $\mathrm{P}_{1}$ represent best parents in the crosses

2. The mid-parent heterosis was calculated as:

$\mathrm{MH}(\%)=\frac{\left(\mathrm{F}_{1}-(\mathrm{P} 1+\mathrm{P} 2) / z\right.}{(\mathrm{p} 1+\mathrm{P} 2) / 2} \times 100$, where $\mathrm{MH}=$ Mid-parent heterosis

3. Economic/ standard heterosis, the superiority of the $F_{1}$ hybrid over the standard commercial hybrid variety, expressed as percentage:

$\mathrm{Hs}(\%)=\frac{(\mathrm{F} 1-\mathrm{Sv})}{\mathrm{Sv}} \times 100$, where, $\mathrm{Hs}=$ standard heterosis, and $\mathrm{S}_{\mathrm{v}}=$ standard variety

The significance test of all the three heterosis was done for each character in reference of least significance difference (LSD) of each character from the analysis of variance both at 5\% and $1 \%$ level of probability.

\section{RESULT AND DISCUSSION}

\subsection{Analysis of Variance and Mean Performance of Parents and Hybrids}

\subsubsection{Phenology and Physiology of the Crop}

The mean squares for four parents and six hybrids of chickpea produced by crossing in half diallel fashion and the two standard checks with respect to seven phenology and physiology traits are presented in Table 2. Analysis of variance revealed the presence of significant $(\mathrm{P}<0.05)$ differences for all the traits viz. days to $50 \%$ flowering, days to $90 \%$ maturity, seed filling duration, grain producing efficiency, biomass producing efficiency and economic growth rate of the crop.

Table-2. Mean values of phenology and physiology of the crop of four parents, six $F_{1}$ hybrids and the two checks of chickpea genotypes

\begin{tabular}{l|l|l|l|l|l|l}
\hline Genotypes & DF & DM & SFD & GPE & BPR & EGR \\
\hline ICC5003 & $54 \mathrm{c}$ & $111.5 \mathrm{cde}$ & $57.5 \mathrm{de}$ & $107.07 \mathrm{cde}$ & $0.29 \mathrm{a}$ & $0.04 \mathrm{a}$ \\
\hline ICC5003 X ICC4918 & $52 \mathrm{c}$ & $111 \mathrm{cde}$ & $59 \mathrm{bcde}$ & $114.06 \mathrm{bcde}$ & $0.20 \mathrm{~cd}$ & $0.023 \mathrm{~cd}$ \\
\hline ICC5003X ICC19180 & $54 \mathrm{c}$ & $109 \mathrm{def}$ & $55 \mathrm{de}$ & $102.06 \mathrm{def}$ & $0.25 \mathrm{abc}$ & $0.04 \mathrm{a}$ \\
\hline ICC5003X ICC19181 & $63.5 \mathrm{~b}$ & $117 \mathrm{~b}$ & $53.5 \mathrm{e}$ & $86.48 \mathrm{ef}$ & $0.21 \mathrm{bcd}$ & $0.021 \mathrm{~cd}$ \\
\hline ICC4918 & $48.5 \mathrm{c}$ & $108 \mathrm{ef}$ & $59.5 \mathrm{bcde}$ & $122.96 \mathrm{bcd}$ & $0.21 \mathrm{bcd}$ & $0.016 \mathrm{~d}$ \\
\hline ICC4918X ICC19180 & $48.5 \mathrm{c}$ & $107 \mathrm{f}$ & $58.5 \mathrm{cde}$ & $120.89 \mathrm{bcd}$ & $0.21 \mathrm{bcd}$ & $0.03 \mathrm{ab}$ \\
\hline ICC4918X ICC19181 & $48.5 \mathrm{c}$ & $114.5 \mathrm{bc}$ & $66 \mathrm{~b}$ & $136.1 \mathrm{bc}$ & $0.15 \mathrm{de}$ & $0.022 \mathrm{~cd}$ \\
\hline ICC19180 & $38.5 \mathrm{~d}$ & $106 \mathrm{f}$ & $67.5 \mathrm{a}$ & $175.37 \mathrm{a}$ & $0.23 \mathrm{abc}$ & $0.018 \mathrm{~cd}$ \\
\hline ICC19180XICC19181 & $47 \mathrm{~cd}$ & $112.5 \mathrm{~cd}$ & $65.5 \mathrm{abc}$ & $141.9 \mathrm{~b}$ & $0.20 \mathrm{~cd}$ & $0.017 \mathrm{~cd}$ \\
\hline ICC19181 & $72.5 \mathrm{a}$ & $127.5 \mathrm{a}$ & $55 \mathrm{de}$ & $75.89 \mathrm{f}$ & $0.12 \mathrm{e}$ & $0.016 \mathrm{~d}$ \\
\hline Arerti & $53.5 \mathrm{c}$ & $114.5 \mathrm{bc}$ & $61 \mathrm{abcd}$ & $114.05 \mathrm{bcde}$ & $0.28 \mathrm{a}$ & $0.024 \mathrm{~cd}$ \\
\hline Natoli & $52 \mathrm{c}$ & $112.5 \mathrm{~cd}$ & $60.5 \mathrm{abcde}$ & $116.35 \mathrm{bcde}$ & $0.26 \mathrm{ab}$ & $0.27 \mathrm{bc}$ \\
\hline GM & 52.7 & 112.6 & 59.87 & 117.77 & 0.21 & 0.25 \\
\hline CV\% & 7.46 & 1.38 & 4.99 & 11.03 & 12.6 & 17.78 \\
\hline
\end{tabular}

Means in column with the same letter is not significantly different from each other, BPR= biomass production rate in \%, CV=Coefficient of variation , DF=days to $50 \%$ flowering (\# of days), DM=days to $90 \%$ flowering (\# of days), EGR= economic growth rate in \%, GM=Grand mean, , GPE=grain production efficiency in $\%$, $\mathrm{SFD}=$ seed filling duration (\# of days).

\subsubsection{Yield and Yield Components}

Analysis of variance indicated that the mean squares for four parents, six hybrids and two checks of chickpea genotypes with respect to grain yield and yield components are presented in Table 3. Results of the analysis showed significant $(\mathrm{P}<0.05)$ differences for all the traits viz. number of pods per plant, biomass yield, grain yield, grain harvest index, 100seed weight, shoot dry weight at maturity, shoot dry weight ratio and grain protein content. 
International Journal of Sustainable Agricultural Research, 2017, 4(2): 50-57

Table-3. Mean values of different grain yield and yield components of four parents and their six F1 chickpea hybrids and two check genotypes

\begin{tabular}{|c|c|c|c|c|c|c|c|c|c|}
\hline Genotypes & NPP & BM & GY & GHI & HSW & SDWM & SDWR & SPC & GPC \\
\hline ICC5003 & $92.5 \mathrm{ab}$ & $0.33 a$ & $0.023 \mathrm{ab}$ & $0.071 \mathrm{abcd}$ & $24.35 \mathrm{a}$ & $49.5 \mathrm{bc}$ & $1.04 \mathrm{bc}$ & $22.65 a$ & $22.7 \mathrm{ab}$ \\
\hline $\begin{array}{l}\text { ICC5003 X } \\
\text { ICC4918 }\end{array}$ & $64.9 \mathrm{cdef}$ & $0.2 \mathrm{~cd}$ & $0.013 \mathrm{~cd}$ & $0.062 \mathrm{bcd}$ & $20.4 b c$ & $49.5 b c$ & $1.04 \mathrm{bc}$ & $22.25 a$ & $20.5 \mathrm{abc}$ \\
\hline $\begin{array}{l}\text { ICC5003 X } \\
\text { ICC } 19180\end{array}$ & $90.7 \mathrm{ab}$ & $0.3 \mathrm{abc}$ & $0.024 a$ & $0.089 \mathrm{ab}$ & $25.48 \mathrm{a}$ & $26.3 \mathrm{e}$ & $0.55 \mathrm{e}$ & $23.9 \mathrm{a}$ & $22.9 \mathrm{a}$ \\
\hline $\begin{array}{l}\text { ICC5003 X } \\
\text { ICC19181 }\end{array}$ & $\begin{array}{l}60.85 \mathrm{cdef} \\
\mathrm{g}\end{array}$ & $0.3 \mathrm{bc}$ & $0.011 \mathrm{~cd}$ & $0.045 \mathrm{~d}$ & $17.85 \mathrm{cde}$ & $39.3 \mathrm{~cd}$ & $0.8 \mathrm{~cd}$ & $23.46 a$ & $20.4 \mathrm{abc}$ \\
\hline ICC4918 & $42 \mathrm{bcd}$ & $0.2 \mathrm{~cd}$ & $0.009 \mathrm{~d}$ & $0.044 d$ & $16.75 \mathrm{de}$ & $43 \mathrm{bcd}$ & $0.9 \mathrm{bcd}$ & $12 \mathrm{c}$ & $12.0 \mathrm{e}$ \\
\hline $\begin{array}{l}\text { ICC4918 X } \\
\text { ICC19180 }\end{array}$ & $108.55 a$ & $0.2 \mathrm{~cd}$ & $0.021 \mathrm{ab}$ & 0.0 & $19.5 \mathrm{bcd}$ & $48.1 b c$ & $0.77 \mathrm{~d}$ & $21.06 \mathrm{a}$ & $20.09 \mathrm{c}$ \\
\hline $\begin{array}{l}\text { ICC4918 X } \\
\text { ICC19181 }\end{array}$ & $77.08 \mathrm{bc}$ & $0.2 \mathrm{de}$ & $0.0146 \mathrm{~cd}$ & $0.085 \mathrm{abc}$ & $18.46 \mathrm{~cd}$ & $36.6 \mathrm{~d}$ & $1.01 \mathrm{bc}$ & $14.5 \mathrm{bc}$ & $12.8 \mathrm{e}$ \\
\hline ICC 19180 & $49.8 \mathrm{efg}$ & $0.3 \mathrm{bc}$ & $0.012 \mathrm{~cd}$ & $0.048 \mathrm{~d}$ & $22.85 \mathrm{ab}$ & $36.6 \mathrm{~d}$ & $0.77 \mathrm{~d}$ & $24.15 a$ & $19.37 \mathrm{~cd}$ \\
\hline $\begin{array}{l}\text { ICC19180 X } \\
\text { ICC19181 }\end{array}$ & $74.4 \mathrm{bcd}$ & $0.2 \mathrm{~cd}$ & $0.011 \mathrm{~cd}$ & $0.051 \mathrm{~cd}$ & $14.85 \mathrm{e}$ & $50.9 \mathrm{~b}$ & $1.07 \mathrm{~b}$ & $20.78 a$ & $19.34 \mathrm{~cd}$ \\
\hline ICC19181 & $44.12 \mathrm{fg}$ & $0.15 \mathrm{e}$ & $0.01 \mathrm{~cd}$ & $0.062 \mathrm{bcd}$ & $19.6 \mathrm{bc}$ & $62.3 a$ & $1.31 \mathrm{a}$ & $16.2 b$ & $12.09 \mathrm{e}$ \\
\hline Arerti & 51.95defg & $0.33 a$ & $0.0146 \mathrm{~cd}$ & $0.045 \mathrm{~d}$ & $17.85 \mathrm{cde}$ & $67.2 \mathrm{a}$ & $1.42 \mathrm{a}$ & $23.7 \mathrm{a}$ & $17.18 \mathrm{~d}$ \\
\hline Natoli & $71.25 \mathrm{bcde}$ & $0.3 \mathrm{ab}$ & $0.016 b c$ & $0.055 \mathrm{bcd}$ & $19.1 \mathrm{~cd}$ & $67.1 \mathrm{a}$ & $1.41 \mathrm{a}$ & $22.9 a$ & $20.2 \mathrm{cb}$ \\
\hline GM & 69.00 & 0.24 & 0.015 & 0.06 & 19.75 & 47.9 & 1.01 & 20.64 & 18.3 \\
\hline CV\% & 14.87 & 12.00 & 17.8 & 24.44 & 8.2 & 9.1 & 9.06 & 9.02 & 5.8 \\
\hline
\end{tabular}

$\mathrm{BM}=$ biomass yield in $\mathrm{kg}, \mathrm{CV}=$ Coefficient of variation, $\mathrm{GHI}=$ grain harvest index in \%, GM=Grand mean, GPC=grain protein content in \%, GY=grain yield per plant in $\mathrm{kg}, \mathrm{HSW}=$ hundred seed weight in gm, NPP=number of pod per plant, SDWM=shoot dry weight at physiological maturity in gm, SDWR= shoot dry weight ratio.

If yield is taken as an ultimate impact indicator of the hetrotic values, there are clear indications that the genetic pool in favor of yield has influenced yield of chickpea (Figure 1). This gain gives favorable indication on genetic gain in chickpea as a factor of mobilization of different cluster of favorable genes using divers combination and evaluation designs.

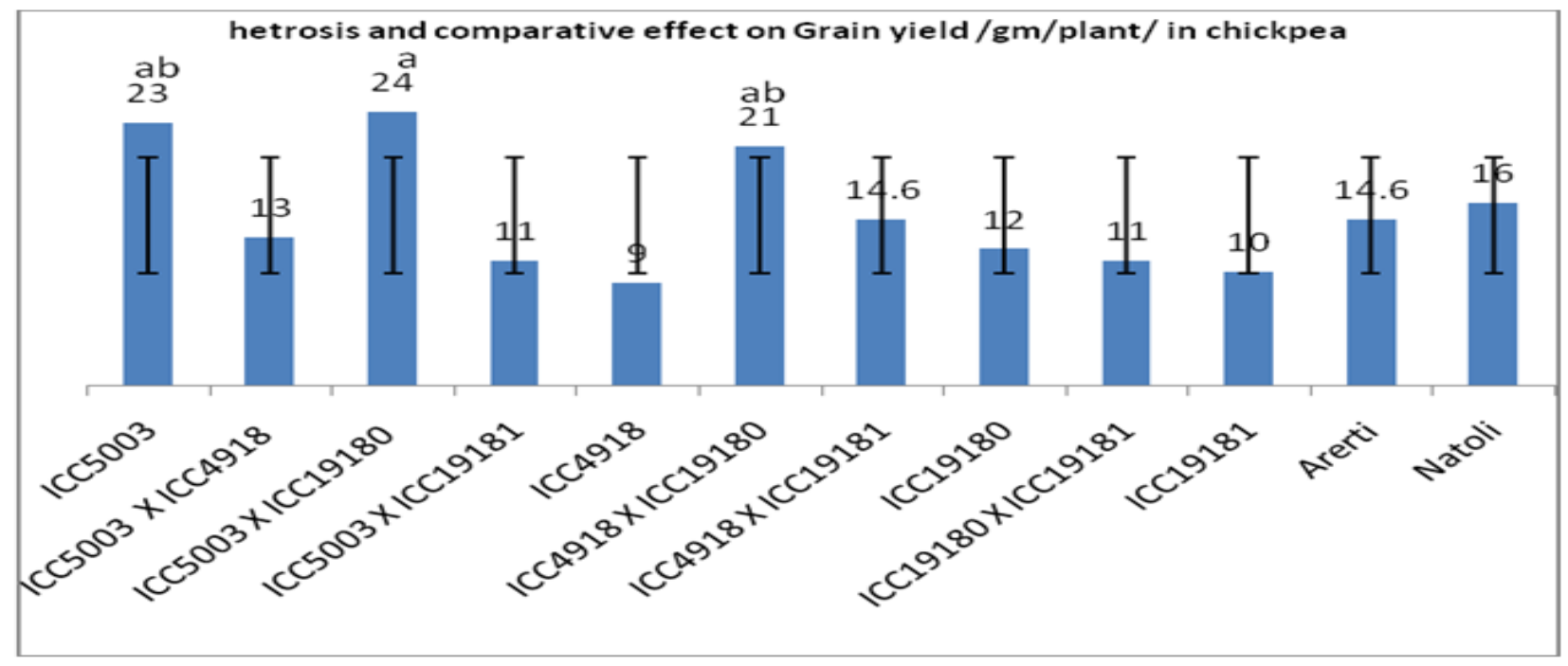

Figure-1. Effective and comparative hetrotic values on economic yield in chickpea

\subsubsection{Symbiosis Parameters}

The analysis of variance (Table 4) revealed a significant difference among number of nodule, shoot nitrogen yield, shoot nitrogen fixation, nitrogen fixed in grain, grain nitrogen yield, biomass nitrogen yield, nitrogen harvest index and nodule dry weight. A significant difference between genotypes with respect to number of nodules per plant was also recorded in this study (Table 5). Variation for number of nodule was recorded in the current study, among nodulated and non nodulated genotypes. 
Table-4. Mean values of symbiosis parameters of 4 parents and $6 \mathrm{~F}_{1}$ chickpea genotypes

\begin{tabular}{l|l|l|l|l|l|l|l}
\hline Genotypes & NN & SNF & NFB & NFG & NHI & GNY & NDW \\
\hline ICC5003 & $52 \mathrm{~b}$ & $45.91 \mathrm{a}$ & $46.52 \mathrm{a}$ & $47.1 \mathrm{a}$ & $0.07 \mathrm{bc}$ & $0.083 \mathrm{a}$ & $71.8 \mathrm{~cd}$ \\
\hline ICC5003XICC4918 & $26 \mathrm{~d}$ & $44.89 \mathrm{a}$ & $43.16 \mathrm{a}$ & $41.2 \mathrm{ab}$ & $0.05 \mathrm{bcd}$ & $0.045 \mathrm{~cd}$ & $95.7 \mathrm{~b}$ \\
\hline ICC5003XICC19180 & $57.3 \mathrm{a}$ & $48.81 \mathrm{a}$ & $48.26 \mathrm{a}$ & $47.7 \mathrm{a}$ & $0.08 \mathrm{a}$ & $0.088 \mathrm{a}$ & $50.9 \mathrm{~d}$ \\
\hline ICC5003XICC19181 & $22.9 \mathrm{~d}$ & $47.70 \mathrm{a}$ & $44.66 \mathrm{a}$ & $41.1 \mathrm{ab}$ & $0.04 \mathrm{~d}$ & $0.036 \mathrm{cde}$ & $48.9 \mathrm{~d}$ \\
\hline ICC4918 & $0.00 \mathrm{~g}$ & $0.00 \mathrm{~b}$ & $0.00 \mathrm{~b}$ & $0.0 \mathrm{~d}$ & $0.044 \mathrm{~cd}$ & $0.018 \mathrm{e}$ & $0.00 \mathrm{e}$ \\
\hline ICC4918X ICC19180 & $14.8 \mathrm{e}$ & $41.57 \mathrm{a}$ & $41.04 \mathrm{a}$ & $40.3 \mathrm{~b}$ & $0.09 \mathrm{a}$ & $0.069 \mathrm{ab}$ & $61.8 \mathrm{~d}$ \\
\hline ICC4918X ICC19181 & $0.00 \mathrm{~g}$ & $13.43 \mathrm{~b}$ & $10.57 \mathrm{~b}$ & $6.3 \mathrm{~d}$ & $0.07 \mathrm{ab}$ & $0.03 \mathrm{de}$ & $0.00 \mathrm{e}$ \\
\hline ICC19180 & $17.8 \mathrm{e}$ & $49.28 \mathrm{a}$ & $44.29 \mathrm{a}$ & $38.1 \mathrm{~b}$ & $0.041 \mathrm{~d}$ & $0.037 \mathrm{cde}$ & $157 \mathrm{a}$ \\
\hline ICC19180XICC19181 & $8.9 \mathrm{f}$ & $40.94 \mathrm{a}$ & $39.52 \mathrm{a}$ & $38 \mathrm{~b}$ & $0.048 \mathrm{~cd}$ & $0.035 \mathrm{cde}$ & $106.8 \mathrm{~b}$ \\
\hline ICC19181 & $0.00 \mathrm{~g}$ & $20.03 \mathrm{~b}$ & $12.89 \mathrm{~b}$ & $0.8 \mathrm{~d}$ & $0.049 \mathrm{~cd}$ & $0.018 \mathrm{e}$ & $0.00 \mathrm{e}$ \\
\hline Arerti & $46.5 \mathrm{c}$ & $48.30 \mathrm{a}$ & $40.60 \mathrm{a}$ & $29.9 \mathrm{c}$ & $0.03 \mathrm{~d}$ & $0.04 \mathrm{~cd}$ & $70.9 \mathrm{~cd}$ \\
\hline Natoli & $23.6 \mathrm{~d}$ & $46.58 \mathrm{a}$ & $43.81 \mathrm{a}$ & $40.6 \mathrm{ab}$ & $0.05 \mathrm{~cd}$ & $0.054 \mathrm{bc}$ & $86.8 \mathrm{bc}$ \\
\hline GM & 22.5 & 37.29 & 34.6 & 30.9 & 0.058 & 0.046 & 62.4 \\
\hline CV\% & 8.4 & 24.4 & 16.6 & 10.9 & 21.6 & 19.5 & 16.8 \\
\hline
\end{tabular}

Means in a column followed by same letter are not significant at $(\mathrm{p} \geq 5)$

$\mathrm{CV}=$ Coefficient of variation , GM=Grand mean, GNY=grain nitrogen yield, NDW=nodule dry weight milligram, NFG=nitrogen fixed in grain, $\mathrm{NHI}=$ nitrogen harvest index in \%, NN=number of nodule, $\mathrm{SNF}=$ shoot nitrogen fixation, $\mathrm{NFB}=$ nitrogen fixed in biomass

\subsection{Heterosis}

Mid-parent heterosis, heterobeltiosis and standard heterosis values were estimated for Phenological and physiological data, Yield and yield component data and Symbiosis data collected (Table 5).

The cross ICC5003XICC19180 revealed the highest heterotic effects for shoot nitrogen fixation, nitrogen fixed in biomass, nitrogen fixed in grain, grain nitrogen yield, nodule dry weight, shoot protein content, grain protein content and economic growth rate over the mid parent. ICC5003XICC4918 showed positive and significant heterosis over the mid-parent for number of nodule, grain nitrogen yield, grain yield and economic growth rate. Significant and positive heterotic value over mid parent was estimated in ICC5003XICC19180 for nitrogen fixed in biomass, nitrogen fixed in grain and grain protein content. Cross ICC4918XICC19180 exhibited the highest heterotic effect over mid parent for number of pod per plant, number of nodule, nitrogen fixed in biomass, nitrogen fixed in grain, grain nitrogen yield, shoot protein content, grain protein content and economic growth rate. From all crosses, ICC4918XICC19180 only revealed the highest heterotic effect for nitrogen fixed in grain over mid parent. However, hybrid ICC19180XICC19181 showed the highest value for heterosis over mid-parent for number of pod per plant, nitrogen fixed in grain, nodule dry weight, shoot protein content and grain protein content (Table 5). This result was in agreemeent with the report of Abdul et al. (1990) for 100seed weight, number of pods per plant, grain yield and harvest index in mung bean. Afsari et al. (2001) reported positve and signifcant heterosis for grain yield, number of pod per plant and biological yield in chickpea but, negative heterosis for 100 seed weight and harvest index. Of the crosses, ICC5003XICC4918 was identified as best progeny for some of the symbiotic triats like shoot nitrogen fixation, nitrogen fixed in biomass, nitrogen fixed in grain, grain nitrogen yield, nodule dry weight, shoot protein content and grain protein content. Therefore, this cross can be used for further heterosis breeding on these symbiotic traits in chickpea.

Best parent heterosis (heterobeltiosis) showed negative and insignificant heterotic effects for most of the traits (Table 5). ICC5003XICC4918 revealed significant heterotic effect over the best parent for number of nodule, grain nitrogen yield, grain yield and economic yield. Cross ICC4918xICC19180 showed the highest heterotic effect over best parent for days to $50 \%$ flowering, number of pod per plant, and economic growth. ICC4918XICC19181 showed positive and significant heterobeltiosis for seed filling duration. But heterotic effect over best parent in ICC19180XICC19181 was positive and significant for days to $90 \%$ maturity and seed filling duration). Similar to current study, in mungbean, Abdul et al. (1990) observed non-significnat heterotic effect (heterobeltiosis) for 100seed weight, number of pod per plant, grain yield and harvest index. Afsari et al. (2001) also observe positive heterosis over best parent for biomass and number of pod per plant in chickpea. 
ICC5003XICC4918 revealed positive and significant heterosis over the standard parents for days to 50\% flowering, days to $90 \%$ maturity, number of nodule, shoot dry weight at maturity, shoot dry weight ratio, and economic growth rate. ICC5003XICC19180 showed significant heterosis over standard parent for days to 50\% flowering, days to $90 \%$ maturity, number of nodule, nitrogen fixed in grain, grain nitrogen yield, grain yield, grain protein content and economic growth rate. Standard heterosis was positive and significant for days to 50\% flowering, days to $90 \%$ maturity and number of nodule, in ICC5003XICC18191. ICC4918XICC19180 exhibited significant heterosis over standard parent for days to $50 \%$ flowering, number of pod per plant, shoot dry weight at maturity, and economic growth rate. ICC4918XICC19181 showed significant heterosis over standard parent for days to 50\% flowering, days to $90 \%$ maturity and shoot dry weight ratio. ICC19180XICC19181 showed only significant heterosis over standard parents for days to $90 \%$ maturity, shoot dry weight at maturity and shoot dry weight ratio (Table 5). Abdul et al. (1990) reported positve and significnat heterosis over standard parents in mung bean for number of pod per plant. Afsari et al. (2001) also found positive standard heterosis for harvest index in chickpea. The result of this study could be an indicator to recognize the most promising genotypes to be exploited either as $F_{1}$ hybrids or as a resource population for further selection.

In self-pollinating crops, the main universal shortcoming in the use of hybrid varieties is the difficulty of producing large quantities of hybrid seed (Saxena and Rupela, 1987; Singh, 2008). The same authors indicated that the difficulty of producing hybrid seeds hinder the utilization of heterosis in chick pea (Saxena and Rupela, 1987) and also the direct utilization of heterosis in legumes is limited due to cleistogamous nature of their flower (Afsari et al., 2001).

Table-5. Mid parent heterosis, heterobeltiosis and standard heterosis

\begin{tabular}{|c|c|c|c|c|c|c|c|c|c|c|c|}
\hline & \multicolumn{3}{|c|}{ ICC5003XICC4918 } & \multicolumn{3}{|c|}{ ICC5003XICC19180 } & \multicolumn{3}{|c|}{ ICC5003XICC19181 } & \multicolumn{2}{|l|}{ LSD } \\
\hline & HM(\%) & $\mathbf{H P}(\%)$ & HS(\%) & HM(\%) & HP(\%) & $\mathbf{H S}(\%)$ & HM(\%) & HP(\%) & $\mathbf{H S}(\%)$ & $5 \%$ & $1 \%$ \\
\hline DF & $1.46^{\mathrm{ns}}$ & $-3.70^{\mathrm{ns}}$ & $35.06^{*}$ & $16.8^{\mathrm{ns}}$ & $0.0^{\mathrm{ns}}$ & $40.26 * *$ & $0.4^{\mathrm{ns}}$ & $17.6^{\mathrm{ns}}$ & $64.9 * *$ & 9.63 & 13.8 \\
\hline DM & $0.31^{\mathrm{ns}}$ & $0.00^{\mathrm{ns}}$ & $14.08 * *$ & $3.6^{\mathrm{ns}}$ & $-2.5^{\mathrm{ns}}$ & $10.56 * *$ & $-6.0^{\mathrm{ns}}$ & $1.9^{\mathrm{ns}}$ & $15.5 * *$ & 3.52 & 5.1 \\
\hline SFD & $-1.69^{\mathrm{ns}}$ & $-10.8^{\mathrm{ns}}$ & $-10.77^{\mathrm{ns}}$ & $-16.9^{\mathrm{ns}}$ & $-24.6^{\mathrm{ns}}$ & $-24.6^{\mathrm{ns}}$ & $-22.9^{n s}$ & $-14.0^{\mathrm{ns}}$ & $-43.1^{\mathrm{ns}}$ & 7.46 & 10.7 \\
\hline NPP & $-4.77^{\mathrm{ns}}$ & $-5.53^{\mathrm{ns}}$ & $30.32^{\mathrm{ns}}$ & $-1.7^{\mathrm{ns}}$ & $-14.6^{\mathrm{ns}}$ & $15.86^{\mathrm{ns}}$ & $-11.1^{\mathrm{ns}}$ & $-26.6^{\mathrm{ns}}$ & $-0.4^{\mathrm{ns}}$ & 25.35 & 36.4 \\
\hline NN & $0.00^{\mathrm{ns}}$ & $-50^{\mathrm{ns}}$ & $46.07 * *$ & $64.2 * *$ & $10.2 *$ & $221.9 * *$ & $-11.9^{\mathrm{ns}}$ & $-56.0^{\mathrm{ns}}$ & $28.7 *$ & 4.2 & 6.0 \\
\hline SNF & $95.56 *$ & $-2.22^{\mathrm{ns}}$ & $-8.91^{\mathrm{ns}}$ & $2.6^{\mathrm{ns}}$ & $6.3^{\mathrm{ns}}$ & $-0.95^{\mathrm{ns}}$ & $44.7^{\mathrm{ns}}$ & $3.9^{\mathrm{ns}}$ & $-3.2^{\mathrm{ns}}$ & 21.63 & 31.1 \\
\hline NFB & $85.55 * *$ & $-7.22^{\mathrm{ns}}$ & $-2.55^{\mathrm{ns}}$ & $6.3^{\mathrm{ns}}$ & $3.7^{\mathrm{ns}}$ & $8.96^{\mathrm{ns}}$ & $50.3^{*}$ & $-4.0^{\mathrm{ns}}$ & $0.8^{\mathrm{ns}}$ & 13.22 & 19.0 \\
\hline NFG & $74.95 * *$ & $-12.5^{\mathrm{ns}}$ & $8.14^{\mathrm{ns}}$ & $12.0^{\mathrm{ns}}$ & $1.3^{\mathrm{ns}}$ & $25.20 * *$ & $71.6 * *$ & $-12.7^{\mathrm{ns}}$ & $7.9^{\mathrm{ns}}$ & 5.89 & 8.5 \\
\hline NHI & $30.23^{\mathrm{ns}}$ & $21.74^{\mathrm{ns}}$ & $21.7^{\mathrm{ns}}$ & $27.3^{\mathrm{ns}}$ & $21.7^{\mathrm{ns}}$ & $21.74^{\mathrm{ns}}$ & $-45.1^{\mathrm{ns}}$ & $-53.3^{\mathrm{ns}}$ & $-39.1^{\mathrm{ns}}$ & 0.07 & 0.1 \\
\hline GNY & $23.53 * *$ & $-16.0^{\mathrm{ns}}$ & $0.00^{\mathrm{ns}}$ & $26.1^{* *}$ & $16.0 * *$ & $38.10 * *$ & $-25.7^{\mathrm{ns}}$ & $-48.0^{\mathrm{ns}}$ & $-38.1^{\mathrm{ns}}$ & 0.02 & 0.0 \\
\hline SNY & $-10.24^{\mathrm{ns}}$ & $-38.7^{\mathrm{ns}}$ & $-18.57^{\mathrm{ns}}$ & $-6.7^{\mathrm{ns}}$ & $-18.3^{\mathrm{ns}}$ & $8.57^{\mathrm{ns}}$ & $33.9^{\mathrm{ns}}$ & $-15.1^{\mathrm{ns}}$ & $12.9^{\mathrm{ns}}$ & 0.21 & 0.3 \\
\hline BNY & $-1.86^{\mathrm{ns}}$ & $-33.1^{\mathrm{ns}}$ & $-12.22^{\mathrm{ns}}$ & $0.0^{\mathrm{ns}}$ & $-11.9^{\mathrm{ns}}$ & $15.56^{\mathrm{ns}}$ & $17.6^{\mathrm{ns}}$ & $-23.7^{\mathrm{ns}}$ & $0.0^{\mathrm{ns}}$ & 0.22 & 0.3 \\
\hline $\mathrm{BM}$ & $-17.86^{\mathrm{ns}}$ & $-30.3^{n s}$ & $-8.00^{\mathrm{ns}}$ & $-3.4^{\mathrm{ns}}$ & $-15.2^{\mathrm{ns}}$ & $12.00^{\mathrm{ns}}$ & $4.2^{\mathrm{ns}}$ & $-24.2^{n s}$ & $0.0^{\mathrm{ns}}$ & 0.07 & 0.1 \\
\hline GY & $10.17^{\mathrm{ns}}$ & $-5.8^{\mathrm{ns}}$ & $-5.80^{\mathrm{ns}}$ & $13.0^{*}$ & $13.0^{*}$ & $13.04 *$ & $-32.8^{\mathrm{ns}}$ & $-40.6^{\mathrm{ns}}$ & $-40.6^{\mathrm{ns}}$ & 0.01 & 0.01 \\
\hline GHI & $34.88^{\mathrm{ns}}$ & $31.8^{\mathrm{ns}}$ & $3.57^{\mathrm{ns}}$ & $14.3^{\mathrm{ns}}$ & $0.0^{\mathrm{ns}}$ & $0.00^{\mathrm{ns}}$ & $-42.9^{\mathrm{ns}}$ & $-54.3^{n s}$ & $-42.9^{n s}$ & 0.09 & 0.1 \\
\hline HSW & $-3.00^{\mathrm{ns}}$ & $-17.7^{\mathrm{ns}}$ & $-10.92^{\mathrm{ns}}$ & $-9.9^{\mathrm{ns}}$ & $-13.3^{\mathrm{ns}}$ & $-6.11^{\mathrm{ns}}$ & $-19.4^{\mathrm{ns}}$ & $-27.8^{\mathrm{ns}}$ & $-21.8^{\mathrm{ns}}$ & 3.75 & 5.4 \\
\hline $\begin{array}{l}\text { SDW } \\
\mathrm{P} \\
\end{array}$ & $7.49^{\mathrm{ns}}$ & $0.00^{\mathrm{ns}}$ & $35.25 *$ & $-38.9^{\mathrm{ns}}$ & $-46.9^{\mathrm{ns}}$ & $-28.1^{n s}$ & $-29.7^{\mathrm{ns}}$ & $-36.9^{n s}$ & $7.4^{\mathrm{ns}}$ & 10.65 & 15.3 \\
\hline $\begin{array}{l}\text { SDW } \\
\mathrm{R}\end{array}$ & $7.22^{\mathrm{ns}}$ & $0.00^{\mathrm{ns}}$ & $35.06 *$ & $-39.2^{\mathrm{ns}}$ & $-47.1^{\mathrm{ns}}$ & $-28.6^{\mathrm{ns}}$ & $-31.9^{\mathrm{ns}}$ & $-38.9^{\mathrm{ns}}$ & $3.9^{\mathrm{ns}}$ & 0.23 & 0.3 \\
\hline NDW & $166.57 * *$ & $33.29^{\mathrm{ns}}$ & $-39.04^{\mathrm{ns}}$ & $-55.5^{\mathrm{ns}}$ & $-67.6^{\mathrm{ns}}$ & $-67.6^{\mathrm{ns}}$ & $36.2^{\mathrm{ns}}$ & $-31.9^{\mathrm{ns}}$ & $-68.9^{n s}$ & 24.53 & 35.2 \\
\hline SPC & $28.53 *$ & $-1.76^{\mathrm{ns}}$ & $7.21^{\mathrm{ns}}$ & $9.9^{\mathrm{ns}}$ & $5.3^{\mathrm{ns}}$ & $14.90^{\mathrm{ns}}$ & $20.8^{\mathrm{ns}}$ & $3.5^{\mathrm{ns}}$ & $13.0^{\mathrm{ns}}$ & 4.22 & 6.1 \\
\hline GPC & $18.16 * *$ & $-9.69^{\mathrm{ns}}$ & $5.67^{\mathrm{ns}}$ & $8.8^{\mathrm{ns}}$ & $0.9^{\mathrm{ns}}$ & $18.04 * *$ & $17.8 * *$ & $-9.7^{\mathrm{ns}}$ & $5.7^{\mathrm{ns}}$ & 2.06 & 3.0 \\
\hline GPE & $-4.19^{\mathrm{ns}}$ & $-16.7^{\mathrm{ns}}$ & $-33.73^{n s}$ & $-32.0^{\mathrm{ns}}$ & $-46.0^{\mathrm{ns}}$ & $-46^{\mathrm{ns}}$ & $-22.9^{\mathrm{ns}}$ & $-38.4^{\mathrm{ns}}$ & $-63.8^{\mathrm{ns}}$ & 31.99 & 46.0 \\
\hline BPR & $-17.65^{\mathrm{ns}}$ & $-30.0^{\mathrm{ns}}$ & $-20.00^{\mathrm{ns}}$ & $-6.7^{\mathrm{ns}}$ & $-12.5^{\mathrm{ns}}$ & $0.00^{\mathrm{ns}}$ & $7.1^{\mathrm{ns}}$ & $-25.0^{\mathrm{ns}}$ & $-14.3^{\mathrm{ns}}$ & 0.06 & 0.1 \\
\hline EGR & $9.52 *$ & $-14.8^{\mathrm{ns}}$ & $9.52 *$ & $33.3 * *$ & $18.5 * *$ & $52.38 * *$ & $-3.8^{\mathrm{ns}}$ & $-7.41^{\mathrm{ns}}$ & $19.0^{\mathrm{ns}}$ & 0.02 & 0.02 \\
\hline
\end{tabular}

$\mathrm{BM}=$ biomass yield, $\mathrm{BNY}=$ biomass nitrogen yield, $\mathrm{BPR}=$ biomass production rate, $\mathrm{DF}=$ days to $50 \%$ flowering, $\mathrm{DM}=$ days to $90 \%$ flowering, $\mathrm{EGR}=\mathrm{economic}$ growth rat $\epsilon$ $\mathrm{GHI}=$ grain harvest index, GNY=grain nitrogen yield, GPC=grain protein content, GPE=grain production efficiency, GY=grain yield, HM=mid-parent heterosis, HP=bes parent heterosis, HS= standard heterosis, HSW=hundred seed weight, NDW=nodule dry, NFB=nitrogen fixed in grain, NFG=nitrogen fixed in grain, NHI=nitroge harvest index, $\mathrm{NN}=$ number of nodule , $\mathrm{NPP}=$ number of pod per plant, $\mathrm{SDWP}=$ shoot dry weight at physiological maturity, $\mathrm{SDWR}=$ shoot dry weight, $\mathrm{SFD}=$ seed fillin duration, $\mathrm{SNF}=$ shoot nitrogen fixation, $\mathrm{SPC}=$ shoot protein content, $\mathrm{SNY}=$ shoot nitrogen yield 
Table-6. Continued

\begin{tabular}{|c|c|c|c|c|c|c|c|c|c|c|c|}
\hline & \multicolumn{3}{|c|}{ ICC4918XICC19180 } & \multicolumn{3}{|c|}{ ICC4918XICC19181 } & \multicolumn{3}{|c|}{ ICC19180XICC19181 } & \multicolumn{2}{|l|}{ LSD } \\
\hline & HM (\%) & $\begin{array}{l}\text { HP } \\
(\%)\end{array}$ & HS (\%) & HM (\%) & $\begin{array}{l}\text { HP } \\
(\%)\end{array}$ & HS $(\%)$ & HM (\%) & $\begin{array}{l}\text { HP } \\
(\%)\end{array}$ & HS (\%) & $5 \%$ & $1 \%$ \\
\hline $\mathrm{DF}$ & $11.5^{\mathrm{ns}}$ & $25.97 *$ & $26.0 *$ & $-19.8^{\mathrm{ns}}$ & $0.00^{\mathrm{ns}}$ & $25.97 *$ & $-15.3^{\mathrm{ns}}$ & $22.08^{\mathrm{ns}}$ & $2207.8^{\mathrm{ns}}$ & 9.63 & 13.8 \\
\hline $\mathrm{DM}$ & $-3.3^{\mathrm{ns}}$ & $3.52^{\mathrm{ns}}$ & $3.5^{\mathrm{ns}}$ & $-8.0^{\mathrm{ns}}$ & $-0.62^{\mathrm{ns}}$ & $13.38 * *$ & $-3.03^{\mathrm{ns}}$ & $12.7 * *$ & $1267.6 * *$ & 3.52 & 5.1 \\
\hline SFD & $-23.1^{\mathrm{ns}}$ & $-23.1^{\mathrm{ns}}$ & $-23 .^{n s}$ & $18.5^{\mathrm{ns}}$ & $48.84 *$ & $-1.54^{\mathrm{ns}}$ & $22.22^{\mathrm{ns}}$ & $53.5 * *$ & $5348.8^{\mathrm{ns}}$ & 7.46 & 10.7 \\
\hline NPP & $83.3 * *$ & $58.1 * *$ & $118.1 * *$ & $27.8^{\mathrm{ns}}$ & $4.80^{\mathrm{ns}}$ & $44.58^{\mathrm{ns}}$ & $59.06 *$ & $49.80^{\mathrm{ns}}$ & $4979.9^{\mathrm{ns}}$ & $\begin{array}{l}25.3 \\
5 \\
\end{array}$ & 36.4 \\
\hline NN & $66.3^{\mathrm{ns}}$ & $-16.8^{\mathrm{ns}}$ & $-16.9^{\mathrm{ns}}$ & $0.0^{\mathrm{ns}}$ & $0.00^{\mathrm{ns}}$ & $-100^{\mathrm{ns}}$ & $0.00^{\mathrm{ns}}$ & $-50^{\mathrm{ns}}$ & $-5000^{\mathrm{ns}}$ & 4.2 & 6.0 \\
\hline SNF & $68.7^{\mathrm{ns}}$ & $-15.6^{\mathrm{ns}}$ & $-15.6^{\mathrm{ns}}$ & $34.1^{\mathrm{ns}}$ & $-32.9^{n s}$ & $-72.7^{\mathrm{ns}}$ & $18.14^{\mathrm{ns}}$ & $-16.9^{\mathrm{ns}}$ & $-1692.4^{\mathrm{ns}}$ & $\begin{array}{l}21.6 \\
3 \\
\end{array}$ & 31.1 \\
\hline NFB & $85.3^{*}$ & $-7.34^{\mathrm{ns}}$ & $-7.3^{\mathrm{ns}}$ & $64.0^{\mathrm{ns}}$ & $-18.0^{\mathrm{ns}}$ & $-76.1^{\mathrm{ns}}$ & $38.23^{\mathrm{ns}}$ & $-10.7^{\mathrm{ns}}$ & $-1076.9^{\mathrm{ns}}$ & $\begin{array}{l}13.2 \\
2\end{array}$ & 19.0 \\
\hline NFG & $111.5 * *$ & $5.77^{\mathrm{ns}}$ & $5.8^{\mathrm{ns}}$ & $1475 *$ & $687.5^{\mathrm{ns}}$ & $-83.4^{\mathrm{ns}}$ & $95.37 * *$ & $-0.26^{\mathrm{ns}}$ & $-26.25^{\mathrm{ns}}$ & 5.89 & 8.5 \\
\hline $\mathrm{NHI}$ & $11.1^{\mathrm{ns}}$ & $8.70^{\mathrm{ns}}$ & $8.7^{\mathrm{ns}}$ & $0.0^{\mathrm{ns}}$ & $-13.3^{\mathrm{ns}}$ & $13.04^{\mathrm{ns}}$ & $-13.21^{\mathrm{ns}}$ & $-23.3^{n s}$ & $-2333.3^{\mathrm{ns}}$ & 0.07 & 0.1 \\
\hline GNY & $26.7 * *$ & $-9.52^{n s}$ & $-9.5^{\mathrm{ns}}$ & $5.3^{\mathrm{ns}}$ & $0.00^{\mathrm{ns}}$ & $-52.4^{\mathrm{ns}}$ & $3.23^{\mathrm{ns}}$ & $-23.8^{n s}$ & $-2380.9^{\mathrm{ns}}$ & 0.02 & 0.0 \\
\hline SNY & $7.7^{\mathrm{ns}}$ & $-20.0^{\mathrm{ns}}$ & $-20.0^{\mathrm{ns}}$ & $-5.1^{\mathrm{ns}}$ & $-17.6^{\mathrm{ns}}$ & $-60^{\mathrm{ns}}$ & $20.00^{\mathrm{ns}}$ & $-18.5^{\mathrm{ns}}$ & $-1857.1^{\mathrm{ns}}$ & 0.21 & 0.3 \\
\hline $\mathrm{BNY}$ & $11.3^{\mathrm{ns}}$ & $-17.8^{\mathrm{ns}}$ & $-17.8^{\mathrm{ns}}$ & $-2.6^{\mathrm{ns}}$ & $-11.6^{\mathrm{ns}}$ & $-57.7^{\mathrm{ns}}$ & $18.40^{\mathrm{ns}}$ & $-17.7^{\mathrm{ns}}$ & $-1777.8^{\mathrm{ns}}$ & 0.22 & 0.3 \\
\hline $\mathrm{BM}$ & $-4.2^{\mathrm{ns}}$ & $-8.00^{\mathrm{ns}}$ & $-8.0^{\mathrm{ns}}$ & $-5.3^{n s}$ & $-21.7^{\mathrm{ns}}$ & $-28^{\mathrm{ns}}$ & $15.00^{\mathrm{ns}}$ & $-8.00^{\mathrm{ns}}$ & $-800^{\mathrm{ns}}$ & 0.07 & 0.1 \\
\hline GY & $-1.7^{\mathrm{ns}}$ & $-15.9^{\mathrm{ns}}$ & $-15.9^{\mathrm{ns}}$ & $-5.9^{\mathrm{ns}}$ & $-9.43^{\mathrm{ns}}$ & $-30.4^{\mathrm{ns}}$ & $-13.11^{n s}$ & $-23.1^{\mathrm{ns}}$ & $-2318.8^{\mathrm{ns}}$ & 0.01 & 0.01 \\
\hline GHI & $4.0^{\mathrm{ns}}$ & $-7.14^{\mathrm{ns}}$ & $-7.1^{\mathrm{ns}}$ & $-1.8^{\mathrm{ns}}$ & $-20.0^{\mathrm{ns}}$ & $0.00^{\mathrm{ns}}$ & $-23.81^{\mathrm{ns}}$ & $-31.4^{\mathrm{ns}}$ & $-3142.8^{\mathrm{ns}}$ & 0.09 & 0.1 \\
\hline HSW & $-3.2^{\mathrm{ns}}$ & $-14.8^{\mathrm{ns}}$ & $-14.8^{\mathrm{ns}}$ & $-0.2^{\mathrm{ns}}$ & $-5.77^{\mathrm{ns}}$ & $-19.3^{\mathrm{ns}}$ & $-30.12^{\mathrm{ns}}$ & $-35.1^{\mathrm{ns}}$ & $-3515^{\mathrm{ns}}$ & 3.75 & 5.4 \\
\hline SDWP & $21.5^{\mathrm{ns}}$ & $12.91^{\mathrm{ns}}$ & $31.4 *$ & $-30.2^{\mathrm{ns}}$ & $-41.3^{\mathrm{ns}}$ & $0.00^{\mathrm{ns}}$ & $2.93^{\mathrm{ns}}$ & $-18.3^{\mathrm{ns}}$ & $-1829.8 *$ & $\begin{array}{l}10.6 \\
5 \\
\end{array}$ & 15.3 \\
\hline SDWR & $-7.8^{\mathrm{ns}}$ & $-14.4^{\mathrm{ns}}$ & $0.0^{\mathrm{ns}}$ & $-8.6^{\mathrm{ns}}$ & $-22.9^{\mathrm{ns}}$ & $31.17 *$ & $2.88^{\mathrm{ns}}$ & $-18.3^{\mathrm{ns}}$ & $-1832.1 *$ & 0.23 & 0.3 \\
\hline NDW & $-21.3^{\mathrm{ns}}$ & $-60.64^{n s}$ & $-60.6^{\mathrm{ns}}$ & $0.0^{\mathrm{ns}}$ & $0.00^{\mathrm{ns}}$ & $-100^{\mathrm{ns}}$ & $36.05 *$ & $-31.9^{\mathrm{ns}}$ & $-3197.4^{\mathrm{ns}}$ & $\begin{array}{l}24.5 \\
3 \\
\end{array}$ & 35.2 \\
\hline SPC & $28.7 *$ & $1.44^{\mathrm{ns}}$ & $1.4^{\mathrm{ns}}$ & $2.8^{\mathrm{ns}}$ & $-10.5^{\mathrm{ns}}$ & $-30.3^{\mathrm{ns}}$ & $30.81 *$ & $16.35^{\mathrm{ns}}$ & $1634.6^{\mathrm{ns}}$ & 4.22 & 6.1 \\
\hline GPC & $28.0 * *$ & $3.61^{\mathrm{ns}}$ & $3.6^{\mathrm{ns}}$ & $6.2^{\mathrm{ns}}$ & $5.79^{\mathrm{ns}}$ & $-34^{\mathrm{ns}}$ & $22.54^{* *}$ & $-0.52^{\mathrm{ns}}$ & $-51.55 *$ & 2.06 & 3.0 \\
\hline GPE & $-31.6^{\mathrm{ns}}$ & $-38.6^{\mathrm{ns}}$ & $-38.6^{\mathrm{ns}}$ & $36.2^{\mathrm{ns}}$ & $-1.79^{\mathrm{ns}}$ & $-21.9^{\mathrm{ns}}$ & $26.80^{\mathrm{ns}}$ & $-14.3^{\mathrm{ns}}$ & $-1431.9^{n s}$ & $\begin{array}{l}31.9 \\
9 \\
\end{array}$ & 46.0 \\
\hline BPR & $-4.8^{\mathrm{ns}}$ & $-14.3^{\mathrm{ns}}$ & $-14.3^{\mathrm{ns}}$ & $0.0^{\mathrm{ns}}$ & $-21.4^{\mathrm{ns}}$ & $-37.1^{\mathrm{ns}}$ & $9.80^{\mathrm{ns}}$ & $-20^{\mathrm{ns}}$ & $-2000^{\mathrm{ns}}$ & 0.06 & 0.1 \\
\hline EGR & $33.3 * *$ & $14.3 * *$ & $14.3 * *$ & $-25.0^{\mathrm{ns}}$ & $-40.00^{\mathrm{ns}}$ & $-28.6^{\mathrm{ns}}$ & $-26.09^{\mathrm{ns}}$ & $-32^{\mathrm{ns}}$ & $-3200^{\mathrm{ns}}$ & 0.02 & 0.02 \\
\hline
\end{tabular}

* significant at 0.05 and 0.01 probability

$\mathrm{BM}=$ biomass yield, $\mathrm{BNY}=$ biomass nitrogen yield, $\mathrm{BPR}=$ biomass production rate, $\mathrm{DF}=$ days to $50 \%$ flowering, $\mathrm{DM}=$ days to $90 \%$ flowering, $\mathrm{EGR}=\mathrm{economic}$ growth rat $\epsilon$ $\mathrm{GHI}=$ grain harvest index, GNY=grain nitrogen yield, GPC=grain protein content, GPE=grain production efficiency, GY=grain yield, HM=mid-parent heterosis, $\mathrm{HP}=$ bes parent heterosis, HS= standard heterosis, HSW=hundred seed weight, NDW=nodule dry, NFB=nitrogen fixed in grain, NFG=nitrogen fixed in grain, NHI=nitroges harvest index, $\mathrm{NN}=$ number of nodule, $\mathrm{NPP}=$ number of pod per plant, $\mathrm{SDWP}=$ shoot dry weight at physiological maturity, $\mathrm{SDWR}=$ shoot dry weight, $\mathrm{SFD}=$ seed fillin duration, $\mathrm{SNF}=$ shoot nitrogen fixation, $\mathrm{SPC}=$ shoot protein content, $\mathrm{SNY}=$ shoot nitrogen yield

\section{SUMMARY AND CONCLUSION}

Chickpea has great importance as food, feed and fodder. Chickpea is valued for its nutritive seeds with high protein content, 25.3-28.9\% after de-hulling. Among the food legumes, chickpea is the most hypocholesteremic agent; germinated chickpea was reported to be effective in controlling cholesterol level in rats. Secretion of leaves, stem and pods consist of malic and oxalic acids, giving a sour taste which are supposed to lower the blood cholesterol levels. The crops medicinal applications include use for bronchitis, aphrodisiac, catarrh, cholera, cutamenia, constipation, diarrhea, flatulence, dyspepsia, snakebite, sunstroke, and warts. Seeds are considered antibilious. However, low attention was given for the crops for the last many years in terms of management and input application.

In the present study analysis of variance showed significant differences among genotypes for all studied agronomic and symbiotic traits. The highest mid-parent heterosis was recorded for nodule dry weight in ICC5003XICC4918 while the lowest was noted for ICC5003XICC19180 for grain yield. High heterobeltiosis was estimated for number of pods per plant in ICC4918XICC19180 and the lowest was observed for ICC5003XICC1918 for grain yield. The highest value for standard heterosis was obtained for number of nodule in hybrid ICC5003XICC19180 whereas; the lowest was noted for grain yield in the same hybrid. Therefore, cross ICC5003XICC19180 is identified as a best hybrid for all the three heterosis; hence, one can use these materials for heterosis breeding. 
Funding: This study received no specific financial support.

Competing Interests: The authors declare that they have no competing interests.

Contributors/Acknowledgement: All authors contributed equally to the conception and design of the study.

\section{REFERENCES}

Abdul, G., Z. Muhammad, B. Ahmed and B. Muhammad, 1990. Heterosis among seven parents and their crosses in Mungbean.

Pakistan Journal of Agricultural Research, 11(3): 169-173. View at Google Scholar

Afsari, S., A. Bakhsh, A. Muhammad, A.M. Haqqani and N. Sara, 2001. Identification of genetically superior hybrid in chickpea (Cicer ArietinumL.). Pakistan Journal of Botany, 33(4): 403-409. View at Google Scholar

Association of Official Agricultural Chemists (AOAC), 1970. Official methods of analysis. 11th Edn., Washington, D.C.,USA: AOAC.

Central Statistical Authority (CSA), 2015. Agricultural sample survey, report on, area and production for major crops (Private Peasant Holdings, Meher Season). Addis Ababa, Ethiopia: Central Statistical Authority.

FAOSTAT, 2012. Retrieved from http://faostat.fao.org/site/567/DesktopDefault.aspx [Accessed 10 January 2012].

Gaur, P.M., S. Tripathi, C.L.L. Gowda, G.V.R. Rao, H.C. Sharma, S. Pande and M. Sharma, 2010. Chickpea seed production manual. Patancheru 502 324. Andhra Pradesh, India: International Crops Research Institute for the Semi-Arid Tropics. pp: 28 .

Griffing, B., 1956. Concept of general and specific combining ability in relation to diallel crossing system. Australian Journal of Biological Sciences, 9(4): 463 - 493. View at Google Scholar | View at Publisher

Khattak, G.S.S., M. Ashraf, M.A. Haq and P. Srinives, 2002. Genetics architecture of seed yield and yield components in mungbean (Vigna Radiata (L.) Wilczek). Tropical Agriculture, 79(4): 260-264. View at Google Scholar

Knights, E.J., N. Acikgoz, T. Warkentin, G. Bejiga, S.S. Yadav and J.S. Sandhu, 2007. Area, production and distribution. In: Chickpea breeding and management, (Yadav, S.S., Redden, R., Chen, W., and Sharma, B., Eds),. Wallingford, UK: CAB. pp: $167-178$.

Saxena, M.C. and O.P. Rupela, 1987. Nodulation and nitrogen fixation in chickpea. In: Saxena MC, Singh KB (Eds)., The chickpea. Willingford, UK: CAB International. pp: 19163.

Singh, K.B., 2008. Chickpea breeding. In: Saxena MC, Singh KB (Eds). The chickpea. CAB Inter6.

\section{BIBLIOGRAPHY}

Gaur, P.M., C.L.L. Gowda, E.J. Knights, T. Warkentin, N. Açikgöz, S.S. Yadav and J. Kumar, 2007. Breeding achievements. In: Chickpea breeding and management. Yadav, S.S. et al., (Eds.), Trowbridge, UK: Cromwell Press. pp: 391-409. 